\title{
FIRST RECORD OF BLACK HENBANE AT LEADER
}

\section{DAISY D. MEYERS, Box 218, Leader, Saskatchewan. SON $1 \mathrm{HO}$}

On 2 June 1992, I photographed a very pretty weed growing in front of the corral at my home, half a mile north of the South Saskatchewan River and two miles east of the Leader Bridge. Several more specimens were found growing in the same location or nearby. They varied in height from one to five feet.

As I had not seen this plant here before, I made an attempt to identify it. In my copy of Wildflowers across the Prairies, it looked like Black Henbane (Hyoscyamus niger). Wanting a second opinion, I took a specimen to the Rural Service Centre in Leader. The secretary, Cheryl Graff, searched through several books and also identified it as Black Henbane. The identification was verified by the Crop Protection Laboratory in Regina.

As Black Henbane was new to the Leader area, a specimen of the plant, including flower and seed pod, were pressed and put on file along with a picture of it. The reference file is available at the Rural Service Centre in Leader.

VANCE, F.R., J.R. JOWSEY and J.S. MCLEAN. 1991. Wildflowers across the Prairies. Western Producer Prairies Books, Saskatoon. 337 pp.

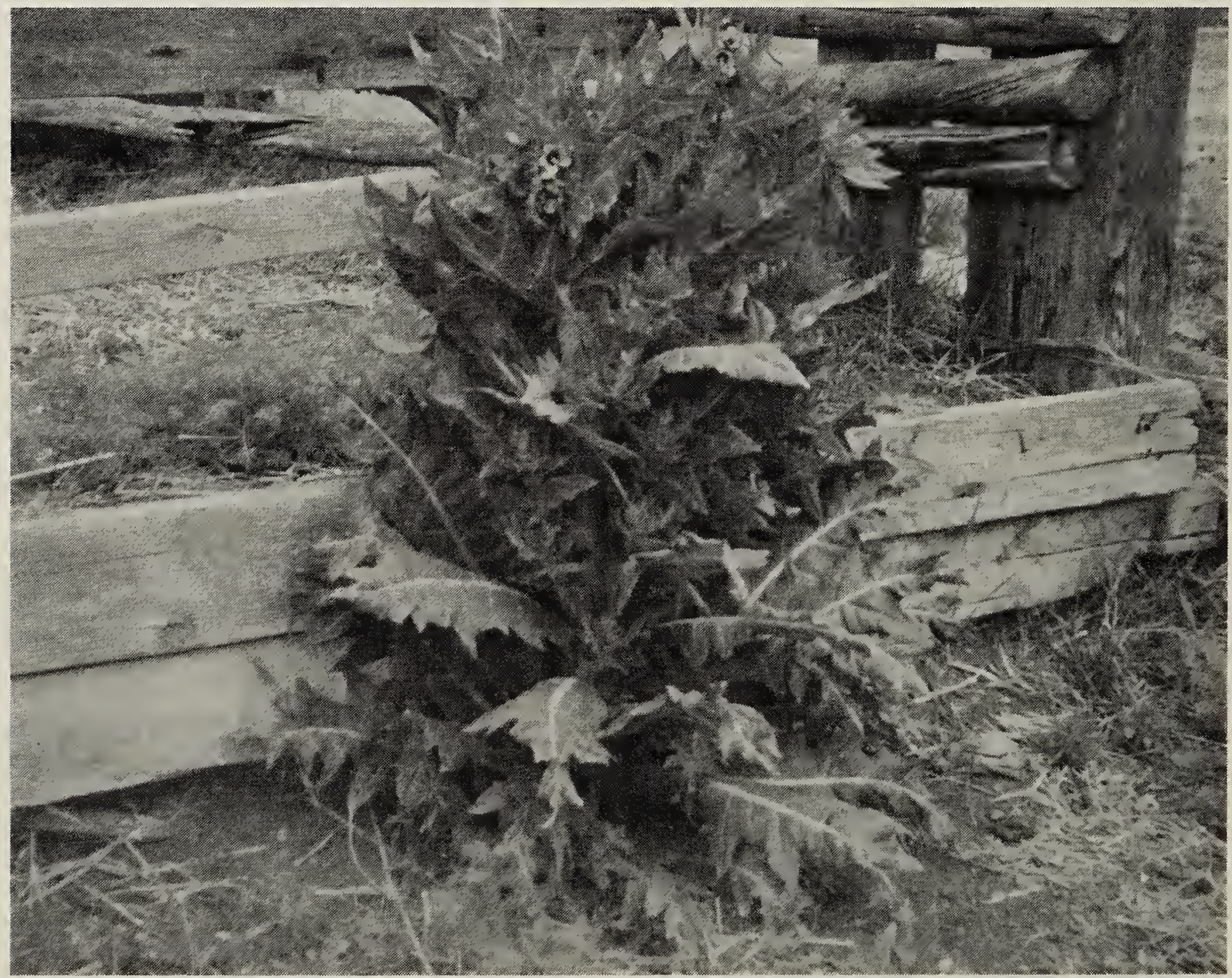

